\title{
DOES WAGE INFLATION CAUSE PRICE INFLATION?
}

\author{
Gregory D. HESS* \\ Oberlin College \\ Shadow Open Market Committee \\ September 1999
}

“Unions Seek Big Pay Gains, Sparking Inflation Worries,” headline, Wall Street Journal, September 3, 1999.

\section{Introduction}

In its quest to understand and anticipate Federal Reserve behavior, Wall Street economists ad journalists have mined the activity in labor markets to help foretell inflationary price pressures. Earlier during the current expansion, journalists and many academics viewed the low rate of unemployment as an indication that rising inflation was near on the horizon. The view was commonly held that if the aggregate demand for goods and services caused unemployment to fall below some 'natural' rate, that inflation would accelerate. However, the rate of unemployment continued to fall throughout the 1990's and yet rising inflation never emerged. This led economists to reconsider whether this 'threshold' unemployment rate, termed the natural or nonaccelerating rate of inflation (NAIRU), had fallen from approximately 6.5 percent to 4.5 percent. Recent work by Staiger, Stock and Watson (1997), however, suggests that even a time varying natural rate of unemployment is not a very useful tool for predicting inflation. ${ }^{1}$

In the aftermath of the demotion of employment variables as early warning devices for rising inflation, recent attention has turned to wage and compensation growth as the current fashionable labor market indicator for inflation. The standard argument for how increased labor costs tend to push up prices, leading to the wage-price spiral, is as follows:

"In developing a framework, we start from the fact that when buoyant demand reduces unemployment (at least relative to recent experienced levels), inflationary pressure develops. Firms start bidding against each other for labor, and workers feel more confident in pressing wage claims. If the inflationary pressure is too great, inflation starts spiraling upwards: 
higher wages lead to higher price rises, leading to still higher wage rises, and so on. This is the wage-price sprial.",

The recent emphasis on whether higher wages will lead to higher prices circumvents the low unemployment part of the above description of the wage-price spiral. In effect, it attempts to understand whether large wage rises will lead to rising inflation even if it does not understand what low unemployment rate will trigger these large wage changes.

The intuition behind the view that higher wages cause higher prices is that since labor costs are a large fraction of a firm's total costs of production, an increase in wages and compensation should put pressure on firms to pass through these higher costs onto higher prices. This story is incomplete, however, for a few reasons. First, an increase in wages will not create inflationary pressure if the increase in wages is brought about by increased labor productivity. Hence, controlling for labor productivity (i.e. supply effects) in the analysis between wages and prices would seem very important. Second, an increase in wages will not create inflationary pressure if the increase in wages leads to a squeeze in a firm's profits due to their inability to pass along cost increases. No firm inherits the right to simply 'mark-up' the prices of its output as a constant proportion above their costs, as competitive market pressures provide a strong influence on the pricing decisions of firms. Finally, the causation could work in the opposite direction: due to an increase in aggregate demand, firms may be able to raise the price of their products and the resulting increase in profits would lead workers to demand a higher wage in future negotiations.

It turns out that the vast majority of the published evidence and the evidence presented below suggests that there is little reason to believe that wage inflation causes price inflation. In fact, it is more often found that price inflation causes wage inflation. Moreover, wage inflation does a very poor job of predicting price inflation throughout the 1990's, while money growth and productivity growth do a much better job. The policy conclusion to be drawn is that inflation can strike unexpectedly without any evidence from the labor market. 


\section{The Evidence}

Before exploring the empirical evidence on this debate, Figure 1 provides a plot of price inflation (as measured by the growth rate of personal consumption expenditure deflator) and wage inflation (as measured by the growth of non-farm business compensation). ${ }^{3}$ The series are graphed over the time period 1960:Q1 to 1999:Q2, with inflation as the solid line and wage growth as the dashed line. Although the growth in wages fluctuates more wildly than does inflation, they generally share the same pattern (the two series have a correlation coefficient of .408): both trended upwards throughout the 1960's and 1970's, they both peaked and tended to decline throughout the 1980's, and then stabilized during the 1990's.

As mentioned above, however, the growth of nominal wages may be a poor measure of cost pressures faced by firms, since if wage growth is driven by productivity growth then the firm will not have to pass on higher wages into higher prices. Fortunately, the Bureau of Labor Statistics also reports unit labor costs, that is the labor cost to the firm for producing one unit of output, which adjusts wages for labor productivity. Figure 2 presents a graph of price inflation and the growth in unit labor costs for 1960:Q1 to 1999:Q2, with inflation again as the solid line and the growth of unit labor costs as the dashed line. One can see that while unit labor costs are quite volatile, they tend to track inflation closely (the two series have a correlation coefficient of .642).

While it is clear that measures of wages and prices strongly co-move with one another, the academic literature is not in complete agreement as to whether there is empirical evidence that wages cause prices. To be clear, academic economists use the term causality as in 'Granger Causality.' The test for Granger Causality involves examining whether lagged values of one series (say wages) have significant in-sample explanatory power for another variable (say prices). Of course, both variables may 'Granger Cause' one another, in which case one can only conclude that both economic series are simultaneously determined and hence a researcher cannot conclude that one series has an independent causal effect on the other. The matter becomes even more complicated if the series in question are 'cointegrated' which is the case if the levels of the series move together over the long run, even though both series individually are best modeled in growth rates. In this case, the researcher must be careful to include 'error 
correction terms' into the Granger Causality tests that allow the series in levels to catch up with one another. The significance of the error correction terms in the Granger Causality test simply reflects the fact that the series in question are driven to return to a long run equilibrium relationship which is non-causal.

Furthermore, researchers find that their conclusions about the causal effects between wages and prices often depend on the sample length, the number of explanatory variables used (including the number of lags of each variable), and the particular measure of prices used. Two recent papers typify the disagreement. Mehra (1993) examines a system of variables that includes inflation, the output gap, unit labor costs as a measure of wages, as well as dummy variables for wage and price controls and a measure of energy prices for the time period (1956:Q1 to 1992:Q4 for the U.S. ${ }^{5}$ He reports that one can only conclude that wages 'Granger Cause' inflation only when one uses the CPI index to measure prices, and that one obtains much stronger evidence that prices Granger Cause wages when one uses the more general GDP price deflator. These results, that prices are more likely to Granger Cause wages than wages Granger Cause prices, are consistent with earlier work by Mehra (1991), Gordon (1988) and Huh and Trehan (1995). ${ }^{6}$ More recently, Ghali (1999) re-explores the econometric issues in Mehra's (1993) paper and modifies the system of variables to include the relative price of imported goods, although he shortens the sample period to 1959:Q1 to 1989:Q3 and only considers prices as measured by the GDP price deflator. ${ }^{7}$ In contrast to the findings by Mehra (1993), Ghali (1999) reports that there is strong evidence that wages Granger Cause prices, and advocates that the Federal Reserve should monitor unit labor costs as a predictor of future inflation.

However, the findings by Ghali (1993), namely that there is strong evidence that aggregate wage movements cause aggregate price movements are atypical and not confirmed by the results I report below. Two additional strands of evidence that suggest that there is not much systematic evidence that wages cause prices. First, Rissman (1995) explores whether there is evidence that sectoral wage growth causes inflation. ${ }^{8}$ She concludes that: "In most of the industries examined, the direction of causality runs from prices to wages rather than wages to prices. Only in manufacturing and retail trade does productivity adjusted wage growth appear to help forecast inflation." Second, Clark 
(1998) has recently explored whether producer prices help to predict consumer prices on both an in-sample (Granger Causality) basis and on an out-of-sample basis. ${ }^{9}$ He finds that while there is evidence that producer prices Granger Cause consumer prices, the nature of these relationships is so fragile that they simply cannot be used on an out-ofsample basis that would be useful for policy purposes.

Table 1 presents my own tests for Granger Causality between wages and prices using the most recent data available. Panel A of the Table reports evidence on which variables cause prices and wages. The regression includes a constant, lagged inflation, lagged money growth, lagged wage growth, lagged productivity, the lagged relative growth in energy and food prices, and dummy variables for the Nixon wage and price controls-see the Data Appendix for a complete description of the data. ${ }^{10}$ The lag length for each variable is set to four. The regression also includes an error correction term that has been estimated to find the long run relationship between the log level of wages, prices, money and productivity. ${ }^{11}$ Each panel first reports the evidence for whether the column variable Granger Causes prices followed by the evidence for whether the column variable Granger Cause wages. The null hypothesis is that there is no Granger Causation, and each column reports the level of statistical significance that one can reject this null hypothesis—so called 'p-values.' In general, a p-value less than .1 is evidence of Granger Causality.

The results in the top panel suggest that for the full sample, 1960:Q1 to 1999:Q2, there is no evidence that wages Granger Cause inflation, but rather that prices are driven by their long run relationship with other variables in the model. In contrast, price inflation and productivity growth Granger cause wage inflation. Again, these results are consistent with those in the literature, with the exception of those by Ghali (1999). For the more recent sample, 1980:Q1 to 199:Q2, wages, productivity and the long run error correction Granger Cause prices, but prices, money, productivity and the long run error correction Granger Cause wages. As is found often in the literature, there is more evidence that wages Granger Cause prices than there is evidence that prices Granger Cause wages.

Panel B of Table 1 re-analyzes whether wages cause prices, except wages are now measured by unit labor costs. The findings suggest that for both samples, prices Granger 
Cause unit labor costs, while only in the full sample is there Granger Causality of unit labor costs on prices. In addition, the long run error correction terms Granger Cause prices in both sub-samples. These findings add further evidence to the view that wages (even corrected for productivity growth) do not have an independent causal effect on prices.

A shortcoming of Granger Causality tests, however, is that they are based on insample estimates of the data. Hence, since financial markets use information to understand future inflation, it is also important to analyze whether empirical models of inflation estimated over one time period (e.g. estimated with data for the 1960's, 70's and 80 's) are useful for forecasting inflation for a later time period (e.g. the 1990's). Results from such a forecasting experiment are presented in Table 2. A number of inflation equations were estimated from 1960:Q1 to 1989:Q4 and then forecasted over 1990:Q1 to 1999:Q2. ${ }^{12}$ The models are labeled in the first column. The 'Univariate' model contains a constant, the lagged price level (in logs), four lags of inflation the lagged relative growth in energy and food prices, and dummy variables for the Nixon wage and price controls - see the Data Appendix for a complete description of the data. The model labeled 'Money,' also include the lagged level of money (in logs) and four lags of money growth. The 'Wage,' 'Productivity' and 'Unit Labor Cost' models are similarly defined. The second column of Table 2 reports the root mean squared errors (RMSE's) of these forecasts - forecasts with lower RMSE's are better than those with higher RMSE's. The third column reports the level of statistical significance at which the Money, Wage, Productivity and ULC models of inflation have lower RMSE's than does the simple Univariate model. The p-value reports the level of statistical significance for the test of null hypothesis that these models do not have lower RMSE's than the Univariate model. P-values less than .1 generally suggest that the models out-forecast the simple Univariate inflation model.

The out-of-sample forecasts confirm that there is no convincing evidence that wages are good at forecasting prices. In fact, the Wage model has the largest forecasting errors. As well, the Unit Labor Cost model does only slightly better than the Univariate model, but not significantly so. Importantly, however, both productivity and money contain essential information for forecasting prices over this time period. Both the 
Money and Productivity models have significantly lower RMSE's than the Univariate model suggesting that those who wish to gauge where future inflation in headed should focus their attention on money supply and productivity developments.

\section{Conclusion}

There is no systematic evidence that wages (either conventionally measured by compensation or adjusted through productivity and converted to unit labor costs) are helpful for predicting inflation. In fact, there is more evidence that inflation helps predict wages. The current emphasis for using labor market activity to forecast short-term inflation pressure would appear, therefore, to be unwarranted. The policy conclusion to be drawn is that inflation can appear regardless of recent wage trends. 


\section{Notes}

*Gregory D. Hess is the Danforth-Lewis Professor of Economics at Oberlin College and a member of the Shadow Open Market Committee. These comments were prepared for the Fall 1999 meeting. He can be reached by email at gregory.hess@ oberlin.edu or by phone at 440-775-8592.

${ }^{1}$ Douglas Staiger, James H. Stock and Mark W. Watson, "The NAIRU, Unemployment, and Monetary Policy," Journal of Economic Perspectives, Winter 1997, 11(1), pp. 33-50.

${ }^{2}$ Richard Layard, Stephen Nickell and Richard Jackman, The Unemployment Crisis, Oxford University Press, 1994, p. 11.

${ }^{3}$ The Data Appendix provides a full description of each series.

${ }^{4}$ The omission of these error correction levels terms in a Granger Causality test specified in growth rates would lead to a standard omitted variable bias in the test for Granger Causality.

${ }^{5}$ Yash P. Mehra, "Unit Labor Costs and the Price Level," Federal Reserve Bank of Richmond, Economic Review, Fall 1993, 79(4), pp. 35-52.

${ }^{6}$ Yash P. Mehra, "Wage Growth and the Inflation Process, "American Economic Review, September 1991, 81(4), pp. 931-937. Robert J. Gordon, "The Role of Wages in the Inflation Process," American Economic Review Papers and Proceedings, May 1988, 78(2), 276-283. Chan G. Huh and Bharat Trehan, "Modeling the Time-Series Behavior of the Aggregate Wage Rate," Federal Reserve Bank of San Francisco, Economic Review, 1995, 1, pp. 3-13.

${ }^{7}$ Khalifa Ghali, "Wage Growth and the Inflation Process: A Multivariate Cointegration Analysis," Journal of Money, Credit and Banking, August 1999, Pt. 1, 31(3), pp. 417-431.

${ }^{8}$ Ellen R. Rissman, "Sectoral Wage Growth and Inflation," Federal Reserve Bank of Chicago, Economic Review, July/August 1995, pp. 16-28.

${ }^{9}$ Todd E. Clark, "Do Producer Prices Help Predict Consumer Prices," Federal Reserve Bank of Kansas City, Research Paper \#97-09, December 1997. 
${ }^{10}$ These Granger Causality tests do not include a measure of the output gap, as recent evidence suggests that they are highly unreliable. Orphanides and van Norden (1999) demonstrate that in some cases the revision in the output gap is as large as the total variability of the output gap. Athanasios Orphanides and Simon van Norden, "The Reliability of Output Gap Estimates in Real Time," Finance and Economic Discussion Series, Board of Governors of the Federal Reserve System, Research Paper \#99-38, August 1999.

${ }^{11}$ As pointed out by Ghali (1999), these cointegrating regressions do not include a constant. They were estimated using the dynamic OLS method of Stock and Watson.

${ }^{12}$ These static forecasts examine how an equation, estimated over one time period, fits over a later sample without re-estimating the empirical relationships. A dynamic forecast would involve estimating an inflation equation and then forecasting each subsequent period based on earlier forecasts. Accordingly, static forecasts do a much better job of predicting than do dynamic forecasts. See also Clark (1997). 


\section{Data Appendix}

Prices: The Personal Consumption Expenditure deflator. The data is seasonally adjusted, quarterly, available from 1947:Q1 to 1999:Q2, 1992=100.

Wages: Nonfarm Business, Total Compensation. The data is seasonally adjsuted, quarterly, available from 1947:Q1 to 1999:Q2, 1992=100.

Unit Labor Costs: Nonfarm Business, Unit Labor Costs. The data is seasonally adjusted, quarterly, available from 1947:Q1 to 1999:Q2, 1992=100.

Productivity: Obtained from the Definition that Wages - Productivity $=$ Unit Labor Costs (in log levels).

Money: The adjusted St. Louis Monetary Base. The data is available from 1950:Q2 to 1999:Q2. Obtained from FRED, Federal Reserve Bank of St. Louis.

Relative Inflation in Food and Energy Prices: The inflation of CPI less the growth rate of the CPI excluding food and energy.

Wage and Price Control Dummy Variables: The first dummy variable takes the value 1 during 1971:Q3 to 1972:Q4 and zero otherwise. The second dummy variable takes the value 1 during 1973:Q1 to 1974:Q4.

The data were transformed by taking logs and quarterly growth rates are annualized. 